\title{
Inferential Pragmatic Analysis of Religious Utterances in Requestives
}

\author{
Reda Ali Hassan Mahmoud \\ Department of English, Faculty of Arts, Minia University, Minia, Egypt
}

Email address:

redaaly@minia.edu.eg

To cite this article:

Reda Ali Hassan Mahmoud. Inferential Pragmatic Analysis of Religious Utterances in Requestives. Communication and Linguistics Studies. Vol. 4, No. 3, 2018, pp. 88-98. doi: 10.11648/j.cls.20180403.14

Received: September 25, 2018; Accepted: October 24, 2018; Published: November 14, 2018

\begin{abstract}
This paper investigates the pragmatic use of religious utterances in requestive speech acts in Egyptian spoken Arabic. The main objective of this study is to explain how the speakers of Egyptian Arabic use metaphysical religious utterances directly and indirectly to perform the materialistic acts of requesting, pleading, petitioning, asking, soliciting, begging, and supplicating. Religious utterances in requestives have been collected from natural talks of various age groups and social backgrounds, social TV series and programs, and movies. The most frequent religious utterances have been sorted out and analyzed in twenty-four examples to identify the types of religious utterances to describe how they occur with requestive sentences and how the users of Egyptian Arabic infer their intended meanings to perform the speech acts of request. The analysis of data exposes two main types of religious utterances which have been referred to as bound and unbound religious utterances. These two types are classified according to their locutionary occurrences with or without requestive utterances in the main unit of discourse which has been given the term global requestive sentence. The analyses of bound and unbound religious utterances and their uses in requestives are based primarily on inferential pragmatics as represented in relevance theory (RT) and Neo-Gricean inferential pragmatics. This inferential pragmatic approach is primarily adopted to explain the inferential processes of religious utterances as locutions and perlocutions to illustrate their roles as facilitators of requestive acts or as part of the communicative illocutionary acts of requests according to the intentions of the speakers. Finally, the study has shown that bound religious utterances are used to facilitate and perform literal requestive acts while unbound religious utterances are often used as nonliteral acts of request which are used mainly as a face-saving strategy.
\end{abstract}

Keywords: Religious Utterances, Requestives, Interferential Pragmatics, Relevance Theory, Communicative Illocutionary Acts, Egyptian Spoken Arabic

\section{Introduction}

Religious utterances in requestives are a preeminent phenomenon in Egyptian spoken Arabic. Speakers of Egyptian Arabic use metaphysical religious utterances frequently to perform several materialistic acts such as requesting, pleading, petitioning, asking, soliciting, begging and supplicating. This study attempts to elucidate the integral role of religious utterances in performing various acts of requests in Egyptian colloquial Arabic. Religious utterances are usually used directly and indirectly by the Egyptian speakers to express their desire to urge the hearers to perform the acts of requests. The term 'requestives' refers to a subtype of 'directives' which is one of the main types of communicative illocutionary acts used by Bach and Harnish
[1] to express the speaker's desire that the hearer does something and the speaker's intention that the hearer takes this expressed desire as reason (or part of his/her reason) to act. Bach \& Harnish have borrowed the term 'directives' from Searle [2-3] which was originally Austin's restricted term 'exercitive' [4]. According to the above definition of requestives, religious utterances in Egyptian Arabic are viewed in this paper as supportive utterances that reflect the speaker's intention to help perform requestive speech acts.

To understand this phenomenon, this study handles religious utterances in Egyptian Spoken Arabic to identify their main types, the uses of these types in combination with requestive utterances, and the intentions of the speakers and the inferences of the hearers on using religious utterances for performing requestive acts. According to these goals, this 
study explores the integral relations between religious and non-religious requestives utterances in Egyptian Arabic to understand their pragmatic functions in terms of the roles of communicative linguistic, contextual, and cultural information in performing these functions.

Despite the frequent use of religious utterances in Arabic spoken discourse, the studies of the pragmatic use of religious utterances in Arabic are very limited. Ali [5] has focused on the role of religious-loaded utterances in phatic communication in Arabic highlighting the social role of religious quotations e.g. prophetic sayings and/or Qur'anic verses in greetings, farewells, and small talk. Several studies in western traditions have emphasized that religious linguistic practices are autonomous and independent of nonreligious forms of life e.g. Beit-Hallahami [6], Proudfoot [7], Ramsey [8] and Wilson [9]. This autonomous view has been opposed by Grennan [10] and Magee [11] by referring to the commissive and assertive forces of religious utterances as seen by believers in religion in Wittgenstein religious language games. According to Wittgenstein's view of language games, Dawes [12] examines the differing pragmatic roles of religious utterances in performing commissive and declarative speech acts in addition to their assertive functions.

In comparison to the above differing views of the functionality of religious utterances in western culture, religious utterances in Egyptian Spoken Arabic when combined with requestive utterances are utilized by the Egyptian speakers to fulfil secular and non-religious acts of requests. Such different functions in Arabic are due to the extensive use of religious utterances in requestives which forms part of their religious and popular culture originally in classical Arabic and later in Egyptian colloquial Arabic. The origin of this phenomenon can be clarified by typical examples from classical Arabic. For instance, the speakers of classical Arabic usually use the name of rab 'God' with many variants of performative verbs of request (e.g. birab/warab alkaYbah iffal ... 'for the sake of the God of Mecca, do ...'; billaahi Salayk ifYal ... 'for God's sake, do ...'). However, this is not the case in English language because the uses of religious utterances such as 'for God's sake' and 'for Christ's sake' are looked upon generally as expressions of annoyance and impatience. Speakers of English use them to add force to an argument when all other reasons fail, or use them as expletives to express anger or irritation, and to strongly emphasize on what they are asking for on feeling desperate that someone fails or is negligent to do something. The use of the name of God in these English expressions has often been taken to cause offense particularly in vain expressions, which encourages English speakers to use euphemism or dysphemism instead of the word 'God' in alternative variants such as 'for goodness sake', 'for heaven's sake', 'for pity's sake', 'for Pete's sake', and 'for crying out loud'. Opposite to the English case which does not encourage the use of religious utterances in speech, the different cultural and social backgrounds of Arabic play a significant motivating role in using and tolerating religious utterances to fulfil requests.

For the purpose of describing religious utterances in requestives, it is necessary to define both of the terms utterance and religious utterance. The term utterance is used in this paper to refer to "the production (oral or written) of a token of a linguistic structure which may or may not correspond to a complete sentence" [13]. According to this definition of utterance, a religious utterance is seen in this study as a religious expression represented linguistically as a phrase or a sentence that includes the name of God, a religious figure, word or symbol. In this sense, the first type of religious utterances is composed of phrases that occur with other requestive utterances and they are mainly intended by the speakers to convince the addressees to react according to their wishes of requesting something. The second type of religious utterances is represented by separate sentences without requestive utterances to achieve different effects on the hearer. Either represented as phrase or sentence, both types of religious utterances, bound or unbound to requestive utterances, are viewed in this paper as linguistic units of communication produced by the speakers in the context of requestive utterances to fulfil a number of communicative acts of requests. The contexts of the above two types of religious utterances are explained and exemplified in the analyses in sections (4-6).

The analyses of the two types of religious utterances and their uses in requestives are based primarily on inferential pragmatics as represented in relevance theory (RT) and NeoGricean inferential pragmatics in section (5). This inferential pragmatic approach is mainly adopted to explain the inferential processes of religious utterances as locutions and perlocutions to illustrate their roles as facilitators of requestive acts or as part of the communicative illocutionary acts of requests according to the intentions of the speakers, the cultural and the social contexts of religious utterances in Egyptian spoken Arabic.

\section{Data}

The data on religious utterances have been collected from the natural colloquial talks of various Egyptians of different social backgrounds while they are requesting or pleading for help in governmental and private sector institutions and organizations such as hospitals and social security agencies in addition to the talks of family members and friends who ask their associates to fulfil certain needs, and simple people and beggars who solicit for money and help. In addition to natural talks, these religious utterances appear frequently in movies, TV series, popular and social TV programs. To determine their degrees of frequency in relation to users, the collected religious utterances have been verified by discourse completion tests (DCTs) gathered from participants of different social backgrounds, age groups, and various educational levels. It is notable that the most frequent uses of religious utterances are associated to certain less-educated or uneducated people of low-intermediate and inferior social backgrounds. The uses of religious utterances are often 
related to the spoken discourse of the former groups of people when they request both money and serious help.

The collected materials of religious utterances are classified to describe their linguistic types, their linguistic occurrences with requestive utterances, and their pragmatic functions and effects in sections (4-7).

\section{Inferential Pragmatic Approach}

In this study, the analyses of the types of religious utterances and their uses in requestives are based primarily on inferential pragmatics as represented in relevance theory (RT) by Sperber and Wilson [14-15] and Wilson \& Sperber [16]. This inferential pragmatic approach is mainly adopted to explain how the hearer infers the speaker's meaning of religious utterances as part of the linguistic communicative acts of requests according to the way intended by the speaker.

For delineating the inferential pragmatic approach, it is significant to show the types of religious utterances and their combination with requestive utterances in global requestive sentence. The data shows that religious utterances often occur in larger units which have been called in this study global requestive sentences. The types of religious utterances are classified according to the order of locutionary utterances or illocutionary forces in global requestive sentences. Global requestive sentence is used in this study to refer to the comprehensive unit of discourse where two locutionary utterances concur in sequence, i.e. when a religious utterance follows or precedes a requestive utterance. Two locutionary occurrences of religious utterances are revealed according to the former classification: bound and unbound religious utterances. Bound religious utterances are combined with requestive utterances and often precede or follow them in global requestive sentences. Unbound religious utterances occur alone without requestive utterances where the act of request is understood indirectly from the context of the utterance despite the absence of the locution of requesting. The two types of bound and unbound religious utterances and their syntactic distribution in addition to their cooccurrences with requestive utterances in global requestives sentences are necessary for understanding their pragmatic functions and meanings.

The selection of the inferential pragmatic approach in RT to analyze bound and unbound religious utterance in global requestive sentences is based on several theoretical considerations that seem more appropriate to explain the inquires which are introduced earlier on the phenomenon in question. The inferential pragmatic approach as presented in the cognitive and communicative principles of RT in Sperber and Wilson [17] can provide the theoretical basis for describing the occurrences of religious utterances, their pragmatic functions, and the relations between religious and requestive utterances in global requestive sentences. According to the cognitive and communicative principles of relevance, it is presumed in this study that the hearer $\mathrm{H}$ infers what is said by the speaker $\mathrm{S}$ depending on the input of linguistic relevance which is achieved by the locutionary sequence of religious and requestive utterances in global requestive sentences. On his/her inference of what is generally said in the global requestive sentence, $\mathrm{H}$ relies on understanding the linguistic sequence of (religious utterance followed by requestive utterance) as intended by $\mathrm{S}$ in case of bound religious utterances. In case of unbound religious utterances, $\mathrm{H}$ infers the indirect nonliteral request according to the contextual communicative information of the utterance which is available to $\mathrm{H}$ in addition to his/her cognitive experiences ${ }^{1}$. The global requestive sentence which includes two locutionary utterances (religious utterance followed by requestive utterance) is used as part of the cognitive input to be inferred by $\mathrm{H}$ as intended by $\mathrm{S}$ to communicate two totally different propositions (viz. metaphysical proposition followed by secular proposition). When $\mathrm{S}$ utters the two locutionary utterances in such a linguistic sequence, $\mathrm{S}$ intends to communicate his/her cognitive input which is inferred by $\mathrm{H}$ as intended by $\mathrm{S}$. $\mathrm{H}$ infers that the first metaphysical proposition in religious utterance facilitates the direct act of request in the second secular proposition. In case of unbound religious utterance, $\mathrm{H}$ infers that $\mathrm{S}$ intends to use the metaphysical proposition of the religious utterance to communicate the indirect nonliteral act of request mainly to save his/her face from asking, requesting or pleading directly, or to utilize the shared religious belief to quicken the response of $\mathrm{H}$, deceive $\mathrm{H}$ in case of begging, or embarrass $\mathrm{H}$ to force him/her to fulfil the act of request.

The previous inferential approach to the analysis of bound/unbound religious utterances in requestives is based on Gricean [18-20] and Neo-Gricean models of inference in Bach \& Harnish [1]. The process of intention-recognition represents the core of the inferential pragmatic approach ${ }^{2}$ in the above two models. Korta \& Perry [21] emphasize that both Gricean and Neo-Gricean models of inference rely on utterance meaning to infer the speaker's communicative intentions. In Grice's casual theory of perception, the dichotomy of intention-recognition, 'what is said and what is implicated' [18] is processed by the systems of cooperative principles and conversational maxims ${ }^{3}$. The inferential model of Bach and Harnish explains the same dichotomy of intention-recognition via the system of mutual beliefs in a linguistic community which are recognized by the illocutionary intent of the speaker [1]. The illocutionary intent of the speaker provides the basis for classifying communicative illocutionary acts [1]. Instead of the above Gricean/Neo-Gricean systems for explaining the inferential process, RT postulates the principles of relevance, emphasizing that the linguistic and cognitive rules of language leave all sorts of issues open for inferencing the

\footnotetext{
1 Demolombe \& Fernndez [23] and Han \& Pereira [24] explain the role of cognitive experiences in the process of intention-recognition and display how the brain calculates the probable reactions to certain situations according to the accumulation of cognitive experiences.

2 For a taxonomy of pragmatic inference, see Horn [25, 26].

3 Hawely [27] explains Grice's distinction between saying and implicating and says it is based on the intuitive distinction between conveying something literally and directly.
} 
intended meaning of the speaker [21]. The linguistic and the cognitive rules of language are also emphasized by Cartson [22] on his description of RT as a psychological theory that departs from Grice's philosophical project to aim at an empirical psychological theory of human cognition of communication.

Among the theoretical considerations for selecting RT inferential approach to analyze religious utterances in requestives is the tolerance of RT with Locke's [28] dyadic model of coding and decoding which has been developed later by Sassure [29], Bloomfield [30], Jakobson [31] and Hjlemslev [32] $]^{1}$. However, Seperber and Wilson in RT have refused the mechanism of coding and encoding and replaced it with intention-recognition (see Cartson [22]; Korta \& Berry [21]). RT takes into account also the concept of presupposition as presented by Stalnaker [33] which combines context with content where what is said is accompanied by intuitions about what is not said, i.e. what is presupposed agrees also with Bach and Harnish's account of direct/indirect - literal/non-literal [1]. According to the above theoretical considerations, RT allows the overt use of linguistic, semantic as well as contextual information as components of the user's cognitive input to infer what $\mathrm{S}$ intends to convey.

Based on the above inferential approach, $\mathrm{H}$ recognizes the order of propositions (metaphysical - secular) depending on the cognitive linguistic order of locutionary utterances (religious - request) which is combined in the requestive global sentence. In the requestive global sentence where religious utterance is bound to request utterance, $\mathrm{H}$ recognizes the direct/literal meaning in requestive utterance without effort relying on linguistic input. $\mathrm{H}$ infers that $\mathrm{S}$ knows that direct/literal meaning is insufficient to fulfil the act of requesting without the use of religious utterance. $\mathrm{H}$ also infers the speaker's locutionary intent of the indirect/non-literal religious utterance as to facilitate the following utterance of request. In unbound religious utterances, $H$ infers the speaker's locutionary intent of indirect/non-literal religious utterance relying on contextual information to fulfil certain functions e.g. to save face from asking, requesting, or pleading directly to facilitate quick response or embarrass the hearer to fulfil the act of request.

As described above, the inferential pragmatic approach will be implemented through the examples in the following sections to illustrate the process of inferring the meanings of both bound and unbound religious utterances to reveal their contexts, illocutionary acts and perlocutionary intents.

\section{The Context of Religious Utterances}

It is essential to delineate the context of religious utterances to explicate their communicative role in requestives. Religious utterances are expressions of religious

1 The triadic model of 'sign', which has been followed by Morris [34] Peirce [35] and their followers, has three components: 'sign vehicle', 'sense' and 'meaning'. This model has been primarily adopted by Plato, Aristotle, and Bacon. content that include the name of Allah and the Prophet to communicate supplication and wishing good for others. According to the earlier definitions of the term utterance in the introduction as a phrase or a sentence, the majority of religious utterance in the data is represented as phrases which are often accompanied by other phrases/sentences that express request in a literal way. Other religious utterances can exist alone as separate sentences unaccompanied by any other utterances (i.e. phrases/sentences indicating request). The former two locutionary types of religious utterances are referred to in this paper as bounded and unbounded utterances to indicate whether they are attached to requestive utterances or not. Bound religious utterances are classified based on their locutionary sequences in global requestive sentences (e.g. religious utterance + requestive utterance or vice versa) and unbound religious utterances occur alone unaccompanied by any other utterances. The following analysis of the two sets of examples (1-2) and (3-6) help elucidate the contextual differences between bound and unbound religious utterances and their role in communicating the intended meanings of the speakers

(1) [rabina yixaliilak welaadak] sallifni 9 a $\int \mathrm{rah}$ gneeh God - keep safe for you - your kids - lend me - ten pounds

'God keep ${ }^{2}$ your kids safe, lend me ten pounds'.

(2) Pifrigha Salayyah rabina yfirigha Saleek

relieve - upon me - God - relieve - upon you

'Relieve me, God relieve you'.

The sentence in example (1) includes two utterances, the religious utterance rabina yixaliilak welaadak 'God keep your kids safe' followed by the requestive utterance sallifni Gajrah gneeh 'lend me ten pounds'. This sequence of utterances (religious - request) is a frequent form of request in Egyptian Arabic where someone in dire need requests something (e.g. money) from someone else. Sometimes, the sequence of utterance is inverted (e.g. request - religious) only to express the pressing need for money. However, in both sequences, the religious utterance is bound and embedded in global requestive sentence to elicit a desired reaction which is explicated by the speaker by uttering the act of request.

Similar to (1), example (2) reflects the same sequence of utterances (request - religious), however the relation between the two utterances is somewhat different. The first utterance in example (2) Pifrigha Salayyah 'relieve me' represents a direct request from $\mathrm{S}$ to get help (relief) from $\mathrm{H}$. The second religious utterance is intended by $\mathrm{S}$ to equate getting help from $\mathrm{H}$ with $\mathrm{H}$ getting help from God. The sequence (request - religious) suggests the speaker's intention of communicating a conditional link 'if you relieve me, God will relieve you/reward you'. It may also suggest the proposition of the speaker that both $\mathrm{S}$ and $\mathrm{H}$ are equal subjects to the relief of God. Whatever the case may be, the

2 The subjunctive mood is used traditionally here in translation to express the speaker's intention, desire, or wish instead of a fact. 
sequence of (request - religious) helps $\mathrm{H}$ infer that $\mathrm{S}$ attempts to solicit money or help via two requests: a direct request represented by the first direct utterance (S requests something from $\mathrm{H}$ ), and an indirect request represented by the religious utterance (that $\mathrm{S}$ requests something for $\mathrm{H}$ ). The second indirect request is recognized by $\mathrm{H}$ as an indirect act of imploring or soliciting money by establishing the conditional link.

The examples in (3-6) are instances of unbound religious utterances.

$$
\begin{aligned}
& \text { rabina yixaliilak welaadak } \\
& \text { God - keep safe for you - your kids } \\
& \text { 'God keep your kids safe'. } \\
& \text { rabina yfirigha Saleek } \\
& \text { God - relieve it - upon you } \\
& \text { 'God relieve you'. } \\
& \text { Pifrigha yarab. } \\
& \text { relieve it - Oh God } \\
& \text { Oh God, relieve it. } \\
& \text { Pifrigha Salayyah. } \\
& \text { relieve it - upon me } \\
& \text { 'Oh God, relieve me.' [supplicating] } \\
& \text { 'Relieve me.' [talking to somebody] }
\end{aligned}
$$

In (3), the religious utterance rabina yixaliilak welaadak 'God keep your kids safe' is not followed or preceded by requestive utterance. In this sense, religious utterance is not bound to any requestive utterance and its meaning can only be inferred according to the speaker's intention of utterance production and the context of the utterance. It is quite difficult to infer the intended meaning of such a type of unbound religious utterances without relying on the context of the utterance and the hearer cognitive experiences to decode the intentions of the speaker. For instance, the speaker may earnestly ask or humbly supplicate God to keep someone's kids safe without asking anything in return (e.g. the act of wishing good for someone). The speaker may also beseech help hoping that his/her act of supplication brings some intended benefit (e.g. the act of begging). Consequently, for such an unbound religious utterance it is difficult to recognize its meaning without relying on the context of situation and the hearer's cognitive experiences to decide upon the speaker's intention of communicating the meanings of the acts of wishing good and begging. The unbound religious utterance in (3) as well as almost all unbound religious utterances in the data are used in the context of begging, beseeching, imploring money or help from the hearer.

The unbound religious utterances in (3) and (4) include particular pieces of grammatical information that facilitate inference. The hearer can easily recognize that $\mathrm{S}$ wants $\mathrm{him} / \mathrm{her}$ to respond via the use of the attached possessive second personal pronoun in welaad-ak 'your kids' in (3), and the second objective pronoun Saleek 'upon you' in (4). The pronouns in addition to other external contextual information (e.g. direct looks, speaker's costume and attitude) can be used by $\mathrm{H}$ as cognitive inputs to decide that he/she is meant by the utterance and consequently he/she has to respond to $\mathrm{S}$.

In (5), the reliance on contextual information increases since the utterance Pifrigha yarab 'Oh God, relieve it' does not include any objective pronoun (cf. the use of pronouns in examples 3 and 4). The hearer has to rely on other external contextual information to infer what is meant by $\mathrm{S}$. The same case is repeated in (6) where the unbound religious utterance Pifrigha Salayyah can be understood as 'Oh God, relieve me' [supplicating] or 'Relieve me' [asking someone for help]. It is difficult to infer from the previous example whether the speaker intends to mean God or the hearer. In both examples, the hearer can infer what is said in terms of external contextual information only.

Further analyses in sections (5) and (6) will clarify the different functions of bound and unbound religious utterances and their various literal and non-literal uses to illustrate their different inferential processes.

\section{Bound Religious Utterances}

The following five examples demonstrate the most frequent types of religious utterances which are bound to request utterances.

(7) $[\text { winnabi }]^{1}$ Pidiini ilkuubaayah di.

for prophet- give me - the glass - this

'[For the prophet's sake], give me this glass'.

[winnabi] nawilni ilkuubaayah di.

for prophet- pass me - the glass - this

'[For the prophet's sake], pass me this glass'.

[wihyaat innabi] xalaSli llmawDuus dah

for life - prophet - solve for me - the problem(topic) - this

'[For the prophet's life], solve this problem for me'.

(10) [rabina yixaliik] kalimli Saћbak.

God - keep you - talk for me - your friend

'[God keep you safe], talk to your friend about my problem'.

(11) [rabina yinagah ma?Sadak] iPDiili Talabi dah

God - make successful - your intents - you finish my request - this

'[God fulfill your deeds], finish this request for me'.

As can be seen, the five examples of global requestive sentences in (7-11) consist of initial religious utterances followed by requestive utterances. It is remarkable that all global utterances in the above examples subsume two different propositions, the first proposition is spiritual/metaphysical (i.e. religious utterance), the second is secular (request utterance). The different propositions in the two utterances are also represented syntactically in two different constructions. The initial religious utterances which are marked by square brackets are composed of the following nominal constructions: wi-nnabi (the particle wi $+n$.) 'for the prophet's sake' in examples (7) and (8), wi-hyaat innabi (the

\footnotetext{
1 Square brackets are used to enclose religious utterances to distinguish them from requestive utterances in global sentences.
} 
particle wi + n. + n.) 'for the prophet's life' in (9), the declarative sentences rabina yixaliik 'God keep you safe' (subj. n. + v.) and rabina yinagah maPaSdak (subj. n. + v. + obj. n.) 'God fulfill your deeds' in (10) and (11).

The second set of requestive utterances consists of verbal constructions (v. + obj. n.) and all of them begin with command verbs e.g. Pidiini 'give me', nawilni 'pass me', xalaSli 'solve for me', kalimli 'talk for me', and i?Diili 'fulfill for me' in examples (7-11) successively.

The following figure (1) illustrates the syntactic differences of nominal and verbal constructions in examples (7-11) and their distributions in global requestive sentences in addition to the types of speech acts and the types of literal/non-literal meanings

\begin{tabular}{|c|c|}
\hline \multicolumn{2}{|c|}{ global utterance } \\
\hline religious utterance & requestive utterance \\
& $\mathbb{\downarrow}$ \\
\hline nominal construction/sentence & verbal sentence \\
\hline declarative sentence & command sentence \\
\hline assertive & requestive \\
\hline speaker & speaker-listener \\
\hline indirect/non-literal & directliteral \\
\hline
\end{tabular}

Figure 1. Distribution of syntactic differences and speech act types of nominal and verbal constructions in global requestive sentences.

In addition to the syntactic and pragmatic information in figure (1), it is clear that the nominal constructions of religious utterances in examples (7-11) are followed by verbal constructions (positive command) of requestive utterances. In contrast, the subsequent religious utterances in (12-13) are composed of verbal constructions and followed by requestive utterances with negative commands

[hallaftak billaah] ma tu?ulf lhad

(I) make swear + you - by Allah - not - to tell - for anybody

'[(I ask you) to swear by Allah] not to tell anybody'.

(13) [hallaftak billaah] ma tiSmils kidah taani

(I) make swear + you - by Allah - not - to do - it again

'[(I ask you) to swear by Allah] not to do it again'.

The religious utterances in examples (12-13) are verbal constructions since they began with the verb hallaft-ak (v. + 2nd person pro.) ' $\mathrm{I}^{1}$ ask you to swear' followed by the name of Allah. In the data, the definite noun Pannabi 'the prophet' is sometimes used by some speakers to replace the name of Allah. The utterance 'to swear by Allah' is a positive command and it is understood by $\mathrm{H}$ as a direct request since it included the direct speech act verb 'swear'.

The other two requestive utterances ma tu?ulf lhad 'not to tell anybody' in (12) and ma ti@mil kidah taani 'not to do it again' in (13) are also verbal constructions that are composed of negative verbal commands. The sequence of utterances (religious + request) in the global requestive sentences is inferred without difficulty as two successive requestive utterances where someone asks another to swear by Allah to

1 The pronoun (I) is often ellipted in Arabic. do a certain thing which is 'not to tell anybody' or 'not to do it again'. The hearer understands directly that the first request by the speaker is to swear by Allah and the second request is not to do a certain action. The hearer infers that the first request in the religious utterances introduces and facilitates for the second main request in the second utterance. The negative command in the second requestive utterance is inferred as the main request intended by the speaker because it includes a perlocutionary effect, i.e. $S$ hopes that $\mathrm{H}$ responds to the request 'not to tell anybody' or 'not to do it again'. To the contrary, the religious utterances in examples $(12,13)$ have limited perlocutionary effects because the speaker uses them only with the intention to introduce or facilitates the second request. Consequently, the perlocutionary effects in the religious utterances which are used as subordinate requests in (12-13) are only limited to introducing and facilitating the main requests in the subsequent utterances.

The following examples exhibit two variants of requestive global sentences where the religious utterances are composed of nominal constructions followed by verbal constructions to represent the requestive utterances

$$
\begin{aligned}
& \text { [winnabi] ma tsaddaPhaa } \\
& \text { for prophet - not - you believe her. } \\
& \text { '[For the prophet's sake], don't believe her'. } \\
& \text { [haraam Saleek] ma tsadda?huu dah [biyfteri Sala } \\
& \text { llaah] } \\
& \text { haram - on you - not - you believe him - this one } \\
& \text { (he)- slander - on (against) - Allah } \\
& \text { '[This is haram], don't believe him, [he slanders } \\
& \text { against Allah.]' }
\end{aligned}
$$

The requestive global sentence in (14) is introduced by the nominal construction winnabi 'for the prophet's sake' which represents the first religious utterance. This nominal construction has the same illocutionary force of the verbal utterance hallaftak billaah 'I ask you to swear by Allah' in examples $(12,13)$ because $H$ infers as if $S$ requests him/her to 'swear by his love to the prophet' not to do a certain action which is represented by the second request utterance ma tsadda?haa 'don't believe her' (neg. verbal command).

In (15), the requestive global sentence is composed of three utterances of which the first and the third utterances are religious and the second is requestive. The two religious utterances are also composed of nominal constructions. The first religious utterance haraam Saleek 'this is haram' is composed of (n. + subj. pro.) and the third one dah biyfteri Sala llaah 'he slanders against Allah' is also nominal (demonstrative pro. + v. + prep. p.). The second requestive utterance ma tsadda?huu 'don't believe him' is a negative verbal command.

The order of religious utterances in (15) reflects the assertive function of the third religious utterance dah biyfteri Sala llaah 'he slanders against Allah' since it provided $\mathrm{H}$ with the adequate reason of the speaker's request in the second utterance ma tsadda?huuf 'don't believe him'. By using the third religious utterance to assert the first, $\mathrm{S}$ also justifies the 
reasons for his/her request in the second utterance. According to the sequence of utterances, the first religious utterance introduces the proposition that a certain action is forbidden (i.e. haram) to warn $\mathrm{H}$ not to believe what a third party says, then the second religious utterance asserts the former proposition by justifying why this action is forbidden. Therefore, both religious utterances in (15), the first and the third, facilitate the processes of providing the adequate reason for a required action and comprehending the action to take the desired effect as intended by the speaker in the main requestive utterance ma tsadda?huuf 'don't believe him'.

Other variants of bound religious utterances are used in requestive global sentences where the requestive utterances are expressed literally.

\section{(16) [wilmasiih ilhayy] da kidb}

for Christ - the living - this - lying.

'[For the living Christ's sake $\left.{ }^{1}\right]$, this is a lie.'

(17) [wilmuShaf iffariif] Pilkalaam dah reer Sahiih for Quran - the holly - the speech - this - not true

'[For the holy Quran's sake], this is not true.'

In $(16,17)$, the initial religious utterances wilmasiih ilhayy 'for the (living) Christ's sake' and wilmuShaf iffariif 'for the holy Quran's sake' are typical nominal constructions. It is remarkable that the requestive utterances in $(16,17)$ are not verbal constructions; they are two referential nominal constructions da kidb 'this is a lie' in (16) and dah reer Sahiih 'this is not true' in (17). Both utterances do not include speech act verbs in comparison to other utterances in (7-15) which often express the acts of request directly. Nevertheless, request in these two nominal utterances is expressed non-literally via lexical negation in the assertive utterance da kidb 'this is a lie' and grammatical negation in dah reer Sahiih 'this is not true' where $S$ asserts a negative proposition in both cases. By using direct assertive utterances, $\mathrm{S}$ also requests $\mathrm{H}$ indirectly to believe in the proposed assumptions that 'this is a lie' or 'not true'. In this case as well, $\mathrm{H}$ infers that $\mathrm{S}$ introduces his/her indirect requests by religious utterances to support his/her proposition and to facilitate responding to the request. In addition, $\mathrm{H}$ infers that the speaker's choice of using nominal rather than verbal constructions is also an attempt to indict a third party indirectly that he/she utters lies and $\mathrm{H}$ has not to believe in these lies.

The following examples of bound religious utterances are related to requestive utterances in global requestive sentences by using assertive grammatical devices

$$
\begin{aligned}
& \text { [wallaahi yaxi] latgibli kubaayat mayyah } \\
& \text { and Allah - my brother - bring me - a glass - water } \\
& \text { '[For Allah's sake], my brother, bring me a glass of } \\
& \text { water.' } \\
& \text { [law intah bithib rabinah] hatli kubaayat mayyah } \\
& \text { if - you - love - God - fetch me - a glass- water } \\
& \text { '[If you love our God], fetch me a glass of water.' }
\end{aligned}
$$

1 The expression wilmasiih ilhayy 'for the living Christ sake' is often used by Muslims of simple cultural backgrounds in rural and popular places.
In (18), the particle 'la' is prefixed to the verb phrase latgibli 'bring me' to be used as an emphasizer ${ }^{2}$ of the topic of the requestive utterance latgibli kubaayat mayyah 'bring me a glass of water'. Badawi et al [36] describe the use of the particle 'la' as an emphasizer when it is prefixed to a verbal element since it serves to strengthen and emphasize an asseveration (i.e. a solemn or emphatic statement of something). In addition to the previous function, the particle ' la' is also used in global requestive sentences to link the nominal religious utterance wallaahi yaxi 'for Allah's sake, my brother' to the following literal verbal request to signify that $\mathrm{S}$ uses the first religious utterance in addition to the emphasizer 'la' in order to assert the topic of request to indulge $\mathrm{H}$ to respond to the request. The above global requestive utterance in (18) is a regular form of request which is often used among youngsters and young friends to indulge each other to fulfil their requests.

The particle law 'if' in example (18) links the religious utterance law intah bithib rabinah 'if you love our God' which forms the protasis of the conditional clause to the request utterance hatli kubaayat mayyah 'fetch me a glass of water' which represents the apodosis, i.e. the clause which expresses the consequence in the conditional sentence ${ }^{3}$. The order of the conditional sentence that begins with the bound religious utterance as protasis followed by the requestive utterance as apodosis suggests that $\mathrm{S}$ intends to use the earlier order of condition to convey to $\mathrm{H}$ the following implied meaning: "if you refuse to fetch me a glass of water, you don't love God'. Relying on shared religious beliefs, S knows that $\mathrm{H}$ is highly unlikely to refuse to respond to his/her request lest anyone accuse him/her of the negative charge of 'refusing to love God'. In turn, $H$ infers that he/she has to respond by complying to the implied request of $\mathrm{S}$ to avoid the negative charge.

The grammatical uses of the particles 'la' and 'law' represent an integral part of the linguistic input which is used in the inferential process of the meanings of the global requestive sentences. The grammatical uses of these particles also represent innovative ways of linking religious to requestive utterances to emphasize the performance of requests as intended by the speakers.

\section{Unbound Religious Utterance}

Unbound religious utterances occur as separate locutions unaccompanied by any other utterances. They are not followed or preceded by requestive utterances. Their literal meanings are composed of religious content while their nonliteral meanings imply request. The analysis of this type of religious utterances in the following examples illustrates their inferential processes and proposes the reasons why $\mathrm{S}$ intends to use them as separate locutionary utterances

2 The definition of the term emphasizer is introduced by Badawi et al [36] to refer to the "heterogeneous class of mostly particles serving to introduce or emphasize topics of phrases".

3 For more information about the form and function of conditional clauses in Arabic, see Badawi et al [36]. 
(20) rabina yixaliik

our God- keep you

'God keep you safe.'

$$
\text { rabbina yinsm Saleek }
$$

our God - endows - you

'God endow you with bless.'

rabbina yibaarik lak fi welaadak/Sihitak

our God - blesses - your kids/health

'God bless your kids/health.'

It is quite difficult to understand the above three examples of unbound religious utterances without relying on their context of situation and the intentions of the speakers. The above three utterances can be understood according to their face-value as utterances of supplication. In all the above utterances, the speakers begin by rabbina 'our God' so as to humbly request God to do something for the addressee, for instance to keep the addressee safe in (20), to bless the addressee in (21), and to bliss the addressee's children or health as in (22). The listener can infer the direct meaning of the above utterances by relying on their linguistic input via the use of the word of God, the speech act verbs in the subjunctive mood 'keep, endow, and bliss' in $(20,21,22)$ respectively in addition to the accompanied objective pronouns. The subjunctive mood is used traditionally here in translating the above three verbs to express the speaker's intention, desire, or wish instead of stating facts. The inference of these literal devices without the real intentions of the speakers represents the illocutionary acts in the three examples as acts of supplication, i.e. someone requests 'or supplicate' God to do something for another. In such cases, the linguistic input of the utterances is not enough to infer what is intended by the speaker. The question why the speaker supplicates for someone else remains unanswered without revealing the main intentions behind the act of supplicating. As part of the inferential process, the hearers have to decode the underlying intentions of the speakers that use the literal acts of supplication to achieve other implicit acts such as the non-literal acts of begging, beseeching or imploring money or help from the hearers. The intentions of the speakers can be inferred by the hearer via decoding the accompanied extralinguistic contextual features of the utterances such as the quality of the humble tone of the speaker's voice, eye-contact with the addressee, body/hand movements, and the impoverished appearance of the speaker. Such extralinguistic contextual features are essential to infer the right intentions of the speakers.

The following unbound utterances in (23-24) show how the speakers utilize some implied expressions to turn the attention of the hearer to his/her intentions.

rabina yikfiik Jarr balaawi zzaman.

our God - protects you from - the evil of time

'God keep you safe from malevolent events.'

Literally, the speaker in the above example supplicates God for keeping the addressee safe. The hearer understands the direct act of supplication easily and infers the indirect reason why the speaker supplicates for him/her, mainly to communicate the indirect act of begging or requesting help. The inferential process of the indirect act of begging or requesting help relies in the hearer's pre-knowledge (i.e. experience) of the speaker whether he/she is a beggar or somebody in need who is requesting help indirectly (e.g. an acquaintance). The pre-knowledge of the hearer constitutes the most integral part of his/her cognitive input to use it to decide upon the right intention of the speaker: 'supplicating directly without secular gains' or 'using the supplication indirectly to ask for something'. The expression Jarr balaawi zzaman 'malevolent events' is often used by beggars to turn the attention of the hearer that the speaker (i.e. the beggar himself/herself) suffers from 'malevolent events' and though wishes the listener to be protected against such events. The former expression is intended by $\mathrm{S}$ to indulge $\mathrm{H}$ react according to the intention of S.

The subsequent example displays another non-literal way for beggars to request money or help.

(24) hasanah Paliilah tidfas balaawi kitiirah handout - small - protects [you against] - many misfortunes

'A little handout protects you against many misfortunes'.

Compared to the utterance in (23), the religious utterance in (24) is not a direct act of supplication because of the exclusion of the word of God in addition to the absence of any pronoun that refers to the addressee. However, the request of money or help in (24) is also expressed indirectly. The hearer infers the indirect act of requesting money or help by relying only on external contextual information (e.g. the impoverished appearance of the beggar, eye-contact, and body/hand movement) in addition to the cognitive linguistic input that beggars often use this expression to elicit money from hearers. The word hasanah 'a handout' is also part of the linguistic input which is used traditionally by the speaker to communicate his/her intentions of begging. The same sense of indulgence in (23) is conveyed in (24) on using the expression tidfaৎ balaawi kitiirah 'protects you against many misfortunes'.

\section{The Functions of Religious Utterances in Requestives}

The prior analyses of bound and unbound religious utterances and their relations to requestive utterances in global requestive sentences reveal two main functions for religious utterances:

(1) Bound religious utterance is used by $\mathrm{S}$ to mediate the linguistic effect of his/her direct literal requestive act by luring $\mathrm{H}$ to perform the illocutionary acts of request. The use of the metaphysical proposition in religious utterance persuades $\mathrm{H}$ to respond to the act of request.

(2) Unbound religious utterance is used by $S$ to save face instead of requesting something literally and explicitly. $\mathrm{H}$ understands that $\mathrm{S}$ needs to request something from 
$\mathrm{H}$, nevertheless $\mathrm{S}$ is unable to express this need literally and explicitly to save face and prefers to gain respect by requesting it nonliterally and implicitly. Therefore, $\mathrm{H}$ is likely to perform and respond to the act of request when it is expressed nonliterally and implicitly.

These two pragmatic functions of religious utterances for performing requestives answer the question why the speakers of Egyptian Arabic use religious utterances of metaphysical propositional content to perform secular acts of request. They explain the inferential process of global requestive sentences which include two incompatible propositions, viz. the metaphysical propositions of religious utterances and the secular propositions of requestive acts. These two functions clarify the intentions of the speakers on using bound and unbound religious utterances both literally and nonliterally as well as the meanings inferred by the hearers which enable them to perform requestive acts.

In terms of the principles of relevance theory, the inferential process of the above two pragmatic functions of religious utterances and their relations to requestive utterances in global requestive sentences is based on the following three types of information:

1. Communicative linguistic information

To understand the meaning of the global requestive sentence, $\mathrm{H}$ relies on the linguistic expression of the literal and explicit SAV of request which is used intentionally by $\mathrm{S}$ to request something from $\mathrm{H}$. Bound religious utterances are used as perlocutions intended mainly to lure $\mathrm{H}$ to react according to the literal and explicit illocutionary acts of request uttered by $S$. The perlocutionary force of the metaphysical proposition in bound religious utterances facilitates the performance of the illocutionary acts of request. The perlocutionary force of the metaphysical proposition represents the common shared belief of religious faith which is recognized and shared by both $\mathrm{S}$ and $\mathrm{H}$, and $\mathrm{S}$ utilizes this perlocutionary force to lure $\mathrm{H}$ to react according to his/her requestive intentions. Though expressed literally and explicitly, the materialistic proposition in the linguistic act of request lacks the sufficient perlocutionary force to convince $\mathrm{H}$ to respond to the act of request. Consequently, the locutionary occurrence of religious and requestive utterances in the global requestive sentence is justifiable by $\mathrm{H}$ who can establish and understand the link between the metaphysical proposition in religious utterances in terms of the materialistic proposition in requestive utterances to facilitate the performance of the illocutionary act of request. As a result, the prediction of $\mathrm{H}$ to react to the literal and explicit illocutionary act of request increases when $\mathrm{S}$ uses religious utterances to induce $\mathrm{H}$ to react to the request of $\mathrm{S}$.

2. Communicative contextual information

The inferential process of the pragmatic function of unbound religious utterance relies on communicative contextual information which integrates into the cognitive input in relevance theory. The hearer infers the nonliteral implicit meaning of request in the global requestive sentence which is composed of a single unbound religious utterance by relying on contextual information. The occurrence of unbound religious utterance - without literal and direct SAVs of request - emphasizes the finding that $S$ uses their metaphysical propositional content together with external contextual information (e.g. the impoverished appearance of the beggar, eye-contact, and body/hand movement) to save face when requesting. The speaker relies on external contextual information which represents the common knowledge shared by both $\mathrm{S}$ and $\mathrm{H}$ to convey the meaning of request without uttering it explicitly.

3. Communicative cultural information

The use of bound/unbound religious utterances to help perform requestive acts is a linguistic as well as a sociocultural norm of many Egyptian users. Hence, the inference of the functions of bound/unbound religious utterances relies on the shared knowledge of this cultural norm among Egyptian speakers. Shared cultural knowledge makes it easier for Egyptians to infer why metaphysical and secular utterances are juxtaposed in global requestive sentences which can be different from other ways of communicating the acts of request in other cultures. The role of shared cultural knowledge increases with the use of unbound religious utterances. The Egyptian hearer is aware of the socio-cultural context when the speaker utters unbound religious utterances to convey his/her unstated desires to request, beg, and to ask for help.

It is important to remark that speakers' communication of requestive acts via the use of religious utterances is intentional. To help perform requestive acts via the use of bound religious utterances, the speakers depend on communicating their literal requests intentionally by uttering the locutionary acts of requests followed by religious utterances to facilitate the performance of requests. Speakers' use of unbound religious utterance without the literal acts of requests is also intentionally meant to save face to entice the hearers to respond quickly and fulfil requests. Contextual cues are usually deliberated intentionally by the speaker to imply the desired effects with religious utterances. Cultural information is inherent in the production and the inference of any acts of communication.

\section{Conclusion}

The main goal of the current study was to determine how the speakers of Egyptian Arabic use metaphysical religious utterances to perform the materialistic acts of requesting, pleading, petitioning, asking, soliciting, begging, and supplicating. The analysis of data has shown two main types of bound and unbound religious utterances which are classified according to their locutionary occurrences with or without requestive utterances in the global requestive sentence, the main unit of discourse. The study has also revealed two main pragmatic functions for bound and unbound religious utterances, viz. to help perform requestive acts and to save face while requesting. These two functions clarify the communicative intentions of the speakers on using bound and unbound religious utterances both literally and 
nonliterally as well as the meanings inferred by the listeners which enable them to perform requestive acts. The interferential process of the pragmatic functions relies on the linguistic, contextual and cultural inputs which are intentionally utilized by the speaker on producing communicative acts of request. The findings of this study suggest that the variation in linguistic, contextual and cultural information may have different implications if the uses of religious utterances in other dialects of Arabic and other languages are subjected to study.

\section{References}

[1] Bach, Kent and Robert M. Harnish. (1979). Linguistic communication and speech acts. Cambridge, Mass.: MIT Press.

[2] Searle, J. (1968). Austin on locutionary and illocutionary acts. Philosophical Review 77, 405-424.

[3] Searle, J. (1969). Speech acts. Cambridge, England: Cambridge University Press.

[4] Austin, J. L. (1962). How to do things with words. Cambridge, Mass.: Harvard University Press.

[5] Ali, A. (2009). High frequency phatic utterances in Arabic: An example of religion-loaded phatic communication. Zeitschrift Für Arabische Linguistik, (50), 22-38.

[6] Beit-Hallahmi, B. (2001) Explaining religious utterances by taking seriously super-naturalist (and naturalist) claims. In: Hon G., Rakover S. S. (eds), Explanation: theoretical approaches and applications, pp. 207-230. Synthese Library (Studies in Epistemology, Logic, Methodology, and Philosophy of Science), vol 302. Springer, Dordrecht.

[7] Proudfoot, W. (1985). Religious experience. Berkeley: University of California Press.

[8] Ramsey, I. (1957). Religious language: An empirical placing of theological phrases. London: SCM Press.

[9] Wilson, J. (1958). Language and Christian belief. London: Macmillan.

[10] Grennan, Wayne. Wittgenstein on religious utterances. International journal of Philosophy and traditions (Sophia), vol. 15 , Issue 3 , pp. 13-18.

[11] Magee, Bryan. (1992) 'Wittgenstein: Dialogue with John Searle'. In The great philosophers, pp. 320-347. Oxford: Oxford university press.

[12] Dawes, George. W. (2016). Religious language. In Religion, philosophy and Knowledge, pp. 7-10. Cham, Switzerland: Palgrave Macmillan.

[13] Sbisà, Marina. (2009). Speech act theory. In Jef Verschueren and Jan-Ola Östman (eds.), The key notions for pragmatics. Amsterdam/Philadelphia: John Benjamins Publishing Company.

[14] Sperber, Dan. \& Wilson, Deirdre. (1986). On defining relevance. In R. Grandy \& R. Warner (eds.), Philosophical grounds of rationality: intentions, categories, ends, pp. 143158. Oxford: Oxford University Press.
[15] Sperber, Dan \& Wilson, Deirdre. (1995). Relevance: Communication and cognition. 2nd edn. Oxford: Blackwell.

[16] Wilson, Deirdre \& Dan Sperber. (2006). Relevance theory. In L. Horn and G. Ward (eds.), The handbook of pragmatics, pp. 607-632. Blackwell Publishing.

[17] Wilson, D. \& Sperber, D. (1993). Linguistic form and relevance. Lingua, 90, 1-25.

[18] Grice, H. P. (1961). The causal theory of perception. Proceedings of the Aristotelian Society, Suppl., Vol. 35, 121 52.

[19] Grice, H. P. (1969). Utterer's meaning and intention. Philosophical Review, 78, 147-77.

[20] Grice, H. P. (2001). Aspects of reason. Oxford: Oxford University Press.

[21] Korta, Kepa and John Perry. (2015). Pragmatics. In Edward N. Zalta (ed.), The Stanford Encyclopedia of Philosophy, Retrieved 02, 08, 2018 from source URL = $<$ https://plato.stanford.edu/archives/win2015/entries/.

[22] Carston, Robyn. (2005). Relevance theory, Grice and the NeoGriceans: A response to Laurence Horn's 'Current issues in neo-Gricean pragmatics.' Intercultural Pragmatics, 2/3, 303319.

[23] Demolombe R., Fernandez A. M. O. (2006). Intention recognition in the situation calculus and probability theory frameworks. In F. Toni, P. Torroni (eds), Computational logic in multi-agent systems. CLIMA 2005. Lecture Notes in Computer Science, vol 3900. Springer, Berlin, Heidelberg.

[24] Han, The Anh \& Pereira, Luís. (2013). State-of-the-art of intention recognition and its use in decision making: A research summary. AI Communications, 26-2, 237-246.

[25] Horn, Laurence R. (1984). Toward a new taxonomy of pragmatic inference: Q-based and R-based implicature. In D. Schiffrin (ed.), Meaning, form and use in context (GURT '84), pp. 11-42, Washington: Georgetown University Press.

[26] Horn, Laurance R. (2006). Implicature. In L. Horn and G. Ward (eds.) The handbook of pragmatics, pp. 3-28. Blackwell Publishing.

[27] Hawely, Patrick. (2002). What is said. Journal of Pragmatics, 34 - 8 (August), 969-991.

[28] Locke, John (1836). An essay concerning human understanding. Twenty-seven edn. London: Tegg \& Son.

[29] Saussure, F., de. (1966). A course in general linguistics. Edited by Charles. Bally \& Albert Riedlinger, Trans. by Wade Baskin. New York, Toronto, London: McGraw-Hill Book Company.

[30] Bloomfield, Leonard. (1933). Language. New York: Henry Holt.

[31] Jakobson, R. (1960). Closing statements: Linguistics and poetics. In T. A. Sebeok (ed.), Style and language, pp. 350377. MIT Press: Cambridge Mass.

[32] Hjelmslev, Louis. (1969). Prolegomena to a theory of language. Trans. by Francis J. Whitfield and Milwaukee Madison. London: University of Wisconsin Press.

[33] Stalnaker, Robert C. (1999). Context and content. Oxford: Oxford University Press. 
[34] Morris, Charles W. (1938). Foundation of the theory of signs. International encyclopedia of unified science, v. 1, no. 2. Chicago: The University of Chicago Press.

[35] Peirce, S. C. (1955). Logic as semiotic: The theory of signs. In Justus Buchler (ed.), Philosophical writing of Peirce, pp. 98115. New York, Dover.
[36] Badawi, Elsaid, Michael G. Carter and Adrian Gully. (2004). Modern written Arabic: A comprehensive grammar. London \& New York: Routledge. 